\title{
Landscape metrics applied in geomorphology: hierarchy and morphometric classes of sand dunes in Inner Somogy, Hungary
}

\author{
Katalin GYÖRGYÖVICS and Tímea KISS ${ }^{1}$
}

\begin{abstract}
Landscape metric is mostly used to quantify landscape patches. However, these patches could also be geomorphological forms, thus using traditional landscape metrics their shape and spatial distribution, or their dynamics could be analysed. The aim of the paper is to study the geomorphological applicability of different indices studying the aeolian forms of Inner Somogy (SW Hungary). In the present research 15 landscape metric indices were calculated with Patch Analyst 5.1 and vLATE 2.0. The negative aeolian forms (blowout depressions and holes) have high number but small size, whilst the positive forms (parabolic dunes and hummocks) have large number and complex spatial structure, thus the negative and positive forms can not be directly connected. The spatial distribution revealed by the applied indices refers to differences in moisture content, abundance of sand supply and relief on a regional scale. The negative forms appear in a considerable distance from each other, while the positive forms tend to cluster. Based on the spatial distribution of the forms the matrix could be described as an erosion-transportation zone, and in three accumulation zones the dune size and superimposition increases downwind.
\end{abstract}

Keywords: landscape metrics, aeolian sand, sand dune morphometry, dune hierarchy, Inner Somogy

\section{Introduction}

Landscape metric is one of the most popular methods for quantitative research of landscape patches. Spatial indices describe the shape and spatial distribution of landscape features, or the connection of patches, therefore landscape dynamics can be analysed (UuemaA, E. et al. 2013). The method is based on the theory of island biogeography by McArthur, R.H. and WiLson, E.O. (1967), however, as computers and remote sensing data became easily available, it was used in increasing number of studies (Turner, M.G. et al. 2001). Easily calculated indices both in vector-based (vLATE in LANG, S. and Tiede, D. 2003; Patch Analyst in REMPEL, R.S. et al. 2012) and raster (Fragstat in McGarigal, K. and Marks, B. 1995) data enhanced widespread use of the method.
Mostly landscape pattern and land use changes are evaluated (Szabó, Sz. et al. 2008; TúrI, Z. 2011; MALAvasi, M. et al. 2013, YE, Y. et al. 2015), but landscape metrics were applied in studies of landscape aesthetic (FrANK, S. et al. 2013), urban fragmentation (HAI, P.M. and Yamaguchi, Y. 2007; Fan, C. and Myint, S. 2014), landscape planning (Csorba, P. 2008; SzABó, Sz. et al. 2012; TuretTA, A.P.D. et al. 2013) and biodiversity change (NAvArroCerrillo, R.M. et al. 2013; Schindler, S. et al. 2015). For example, this method was used to determine that landscape pattern influences sediment dynamics and water quality (SzILAssi, P. et al. 2010; Su, Z.H. et al. 2015), and to study the possibilities of landscape boundaries determination (Mezôsı, G. and BAtA, T. 2011). Zboray, Z. and Kevei-BÁRÁnY, I. (2005) and Telbisz, T. (2011) analysed morphometric

\footnotetext{
${ }^{1}$ Department of Physical Geography and Geoinformatics, University of Szeged, H-6722 Szeged, Egyetem u. 2-6. E-mails: katalingy87@gmail.com, kisstimi@gmail.com
} 
parameters of karst forms using DEM. Scale and resolution dependency and efficiency of the indices was tested (RicotTA, C. et al. 2003; Buyantuyev, A. et al. 2010; Morelli, F.F. et al. 2013), Crushman, S.A. et al. (2008) examined the individual applicability of the indices, while Szabó, Sz. $(2009,2011)$ compared the contagion type indices.

Geomorphological forms could be considered as (ir)regular shaped patches too, thus using traditional landscape metrics their shape and spatial distribution, as well as their dynamics could be analysed. The aim of the present paper is to study the geomorphological applicability of different indices studying the aeolian forms of Inner Somogy (SW Hungary). Our previous studies (KIss, T. et al. 2012, GYörgyövics, K. and KIss, T. 2013) proved that the positive and negative aeolian forms of East Inner Somogy show well-defined spatial configuration and their development is interdependent, so their spatial distribution could be described by applying particular landscape indices. Therefore the aim of the present study is to quantitatively analyse the spatial distribution of aeolian landforms, determine the differences between the features and examine their spatial characteristics, thus to test the applicability of landscape metric indices in geomorphology. In the present study features or forms are mentioned instead of patches to emphasise the geomorphologic aspect of the research.

\section{Study area}

Inner Somogy is located in the Carpathian Basin (Hungary), in Transdanubia, southwest of Lake Balaton. Two joint sand regions are partly divided by a wedge-shaped loess ridge. Detailed research was carried out in East Inner Somogy (its area is $1,610 \mathrm{~km}^{2}$ ) (Figure 1).

Faulted and vertically shifted Variscan blocks built up the substrate of the area (Marosi, S. 1970) which are covered by Pannonian Sea and Lake sediments in various thickness (SüMEGHY, J. 1953). The Danube and its tributaries built an alluvial fan and filled up the territory during the Pliocene or Early Pleistocene (Ádám,

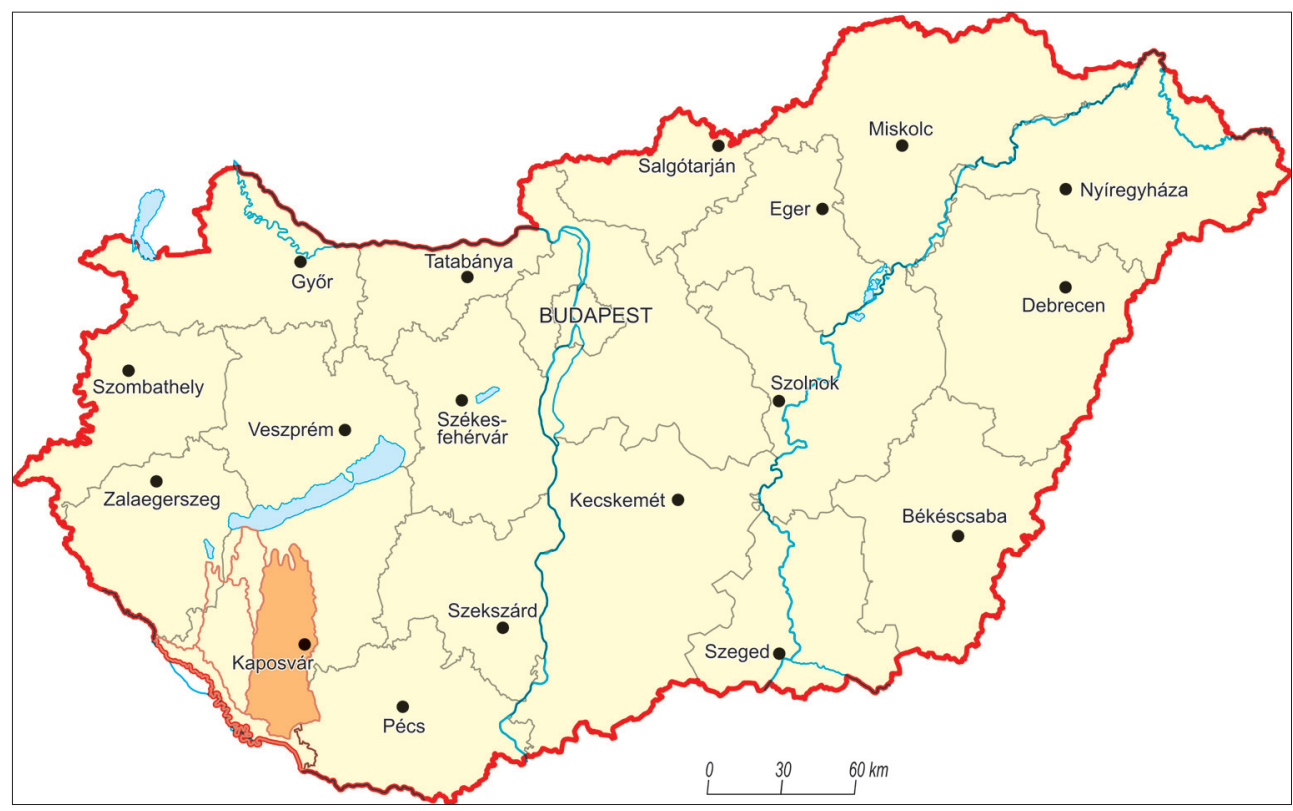

Fig. 1. Location of the study area 
L. et al. 1981). After the Danube abandoned the region, smaller brooks kept North-South flow direction. Aeolian processes became dominant in the Würm (Weichselian glaciation) (Marosi, S. 1970). Prevailing northerly winds reworked and sorted the fluvial sediments, thus the transported blown sand became finer southward (LókI, J. 1981). During the Holocene gullies and erosional valleys formed (Marosi, S. 1970). SEBe, K. et al. (2011) emphasized the role of wind and described the region as a yardang-system.

A central deflation hollow and an entangled accumulation area in South Inner Somogy was described by CHOLNOKY, J. (n.d.) in the early $20^{\text {th }}$ century. Marosi, S. $(1967,1970)$ identified the blowout - residual ridge - hummock system and recognised dune generations, which indicated long-lasting aeolian development. LóKI, J. (1981) revealed a complex system of dunes and ridges, and identified blowout holes, asymmetric parabolic dunes, oval-shaped and elongated hummocks. Based on optically stimulated luminescence dating aeolian activity took place in the Late Glacial, in the Boreal Phase and in historical times (KIss, T. et al. 2012).

Before we started the landscape metric study, we identified and classified the aeolian forms of East Inner Somogy based on their hierarchy and morphometric parameters. Five superimposed hierarchy levels were identified within the positive forms. Simple dunes are positive forms which stand by themselves and lack superimposition. Superimposed dunes appear in four hierarchy levels (level $1-4)$, where dunes in hierarchy level 1 create the base being the largest; whilst hierarchy level 4 dunes are located in the highest regions. Positive and negative aeolian forms were also classified according to their morphometric parameters (KIss, T. et al. 2012; GYörgyövics, K. and KIss, T. 2013).

\section{Methods}

In earlier studies (KIss, T. et al. 2012, GYöRGYövics, K. and KIss, T. 2013) the hierarchical and morphometric classes of positive and negative aeolian forms were described, and these forms were used as the basic database of the landscape metric research. Metric indices were computed in ArcGIS 10 with Patch Analyst 5.1 (Rempel, R.S. et al. 2012) and vLATE 2.0 (LANG, S. and Tiede, D. 2003) extensions and certain parameters were calculated in MS Excel. The form-free area was considered as matrix, but it was not analysed in detail due to the geomorphological aspect of this research. Aeolian forms stretching behind the regional boundary were involved in the analysis with their full extent. Table 1 contains all used indices and their definitions.

The boundary of the study area was defined based on the conventionally accepted regions of Hungary (GóczÁN, L. 1961; PÉcSI, M. and Somogyı, S. 1967). Within the study area the (morphological) zones were defined based on the dominance of the forms: superimposed positive forms dominate in the accumulation zones, while in the erosiontransportation zone (= matrix) lonely aeolian forms developed.

To analyse the distribution of the forms the study area was dissected into $1.0 \mathrm{~km}^{2}$-size hexagonal units. The landforms were converted into points, which were always located within the original form, usually close to the summit of the dune-head or in the deepest part of a negative form. Therefore, the hexagonal units did not cut through the forms, so all of them were examined just once. The hexagonal units were grouped for analysis using the Natural Breaks method, which creates groups by defining the breakpoint of the distribution curve.

\section{Results and discussion}

\section{General characteristics}

Positive forms cover 20.7 percent of the region, while negative features only 3.3 percent (Table 2). However, the number of negative forms is lower, as 4,404 positive and 2,911 negative features were identified. Therefore, the form density of positive forms is 2.74 
Table 1. Definition of landscape indices used in this study

\begin{tabular}{|c|c|}
\hline Landscape index & Definition \\
\hline Total area (TA), $\mathrm{km}^{2}$ & $\begin{array}{l}\text { The area of the region or zone studied containing all studied forms and } \\
\text { the areas without forms. }\end{array}$ \\
\hline Total form area (TFA), $\mathrm{km}^{2}$ & Sum of the territory of all studied forms. \\
\hline Coverage, $\%$ & $\begin{array}{l}\text { Sum of form areas compared to the area of the studied region/zone, TFA/ } \\
\text { TA } x 100 .\end{array}$ \\
\hline Number of patches (NP) & Total number of studied forms. \\
\hline Form density, form $/ \mathrm{km}^{2}$ & Average number of forms on $1 \mathrm{~km}^{2}$ of the total area, NP/TA. \\
\hline Specific form number, form $/ \mathrm{km}^{2}$ & Average number of forms on $1 \mathrm{~km}^{2}$ of the total form area, NP/TFA. \\
\hline Total edge (TE), km & Sum of the perimeters of all studied forms. \\
\hline Edge density, km/km² & Average perimeter on $1 \mathrm{~km}^{2}$ of the total area, TE/TA. \\
\hline Shape index & $\begin{array}{l}\text { The perimeter of a form divided by the perimeter of the circle with the } \\
\text { same area as the form. }\end{array}$ \\
\hline Perimeter-area ratio & Perimeter/area ratio of a form. \\
\hline Total volume, $\mathrm{km}^{3}$ & $\begin{array}{l}\text { Volume of the solid figure close to the 3D shape of the form, calculated as } \\
\text { the third of the area multiplied by height/depth, } V=(\mathrm{T} \times \mathrm{m}) / 3 \text {. }\end{array}$ \\
\hline Shannon's Diversity Index & $\begin{array}{l}\text { Index of form variety. The value is } 0.0 \text { if only one form is located in the } \\
\text { study site, and it increases as classes and form distribution between } \\
\text { classes increases. }\end{array}$ \\
\hline Shannon's Evennes Index & $\begin{array}{l}\text { It shows the distribution of forms between form classes. The value is } \\
0.0 \text { when all forms belong to one class, and it approaches } 1.0 \text { when the } \\
\text { distribution is more even. }\end{array}$ \\
\hline Dominance & $\begin{array}{l}\text { It shows the dominance rate of the prevalent form-class based on area } \\
\text { coverage. }\end{array}$ \\
\hline Nearest neighbour distance, $\mathrm{m}$ & $\begin{array}{l}\text { Distance of the nearest neighbour of a form is the length of the shortest } \\
\text { straight line (Euclidian distance) from the boundary of the form to the } \\
\text { closest boundary of the neighbouring form. }\end{array}$ \\
\hline
\end{tabular}

Table 2. Comparison of the indices of positive and negative forms

\begin{tabular}{|c|c|c|c|}
\hline Landscape index & \multicolumn{2}{|c|}{ Positive forms } & Negative forms \\
\hline Total area, $\mathrm{km}^{2}$ & \multicolumn{3}{|c|}{$1,610.14$} \\
\hline Total form area, $\mathrm{km}^{2}$ & \multicolumn{2}{|c|}{333.93} & 53.14 \\
\hline Coverage, $\%$ & \multicolumn{2}{|c|}{20.74} & 3.30 \\
\hline Number of patches & \multicolumn{2}{|c|}{4,404} & 2,911 \\
\hline Form density, form $/ \mathrm{km}^{2}$ & \multicolumn{2}{|c|}{2.74} & 1.81 \\
\hline Specific form number, form $/ \mathrm{km}^{2}$ & \multicolumn{2}{|c|}{13.19} & 54.78 \\
\hline Mean form area, $\mathrm{km}^{2}$ & \multicolumn{2}{|c|}{0.08} & 0.02 \\
\hline Form area standard deviation, $\mathrm{km}^{2}$ & \multicolumn{2}{|c|}{0.27} & 0.03 \\
\hline Total edge km & \multicolumn{2}{|c|}{$6,330.30$} & $1,548.66$ \\
\hline Mean form edge, $\mathrm{km}$ & \multicolumn{2}{|c|}{1.44} & 0.53 \\
\hline Shape index & \multicolumn{2}{|c|}{1.67} & 1.26 \\
\hline Perimeter-area ratio & \multicolumn{2}{|c|}{0.03} & 0.05 \\
\hline \multirow[t]{2}{*}{ Total volume, $\mathrm{km}^{3}$} & \multicolumn{2}{|c|}{0.85} & 0.02 \\
\hline & $\begin{array}{c}\text { Morphological } \\
\text { class }\end{array}$ & Hierarchy level & $\begin{array}{c}\text { Morphological } \\
\text { class }\end{array}$ \\
\hline Shannon's Diversity Index & 1.71 & 0.97 & 1.20 \\
\hline Shannon's Evenness Index & 0.88 & 0.60 & 0.87 \\
\hline Dominance & 0.24 & 0.64 & 0.18 \\
\hline Nearest neighbour distance, $\mathrm{m}$ & \multicolumn{2}{|c|}{44} & 170 \\
\hline Nearest neighbour distance for classes, $\mathrm{m}$ & 323 & 119 & 376 \\
\hline
\end{tabular}


form $/ \mathrm{km}^{2}$ and of the negative ones is only 1.81 form $/ \mathrm{km}^{2}$. To calculate specific form number the number of patches was divided by the total form area. This index is considerably higher for negative forms, than for positive ones, referring to many small negative features and larger and complex positive dunes. This difference in size is also expressed by the average form area, which indicates that material deflated from several smaller blowouts was deposited in one larger dune.

The standard deviation of form area is an order of magnitude higher in case of positive forms than in negative ones, which suggests that the sand eroded from small blowouts did not always built up large dunes, but in some cases it was stabilized in small forms. The total edge of positive forms is multiple of the value of negative forms due to the more complex and dissected dune shape. Mean perimeter/area ratio refers to more irregular shaped negative forms than positive ones which is a result of more elongated shape of blowouts compared to the compact-shaped dunes. However, the mean shape index, which indicates roundness, is higher for positive forms referring to more complex dune base lines than for the rounded blowout holes.

Total volume describes 3D-shape of the aeolian landforms. For the positive forms it is ca. 50-times higher than total negative form volume. The considerable difference is partly the result of the volume calculation method and partly of the development history of the forms. Errors in the volume calculation originates from (1) the error of the topographic map which is 2-3 m (DivénYI, P. 2001); (2) using cones to approach the 3D forms by considering their area and highest/deepest point; (3) automatic determination of negative forms which only includes endorheic features, however blowouts can be much larger and nonendorheic erosion areas could also develop (LóKI, J. 1981). Moreover, the geographical reason for the large difference in volume might be (1) the erosion of inter-dune areas besides deflation from blowouts (Marosi, S. 1970); (2) sand could had been transported from outside the region (Marosi, S. 1970); and (3) negative forms might be partially or totally filled by younger sand movements, gelisolifluction or slope wash (LóKI, J. 1981).

In our previous research positive forms were grouped to five hierarchy levels based on their superimposition and seven morphometric classes according to their shape (Györgyövics, K. and Kiss, T. 2013), while negative forms were divided to four morphometric classes. Thus, diversity indices for positive landforms were calculated and analysed for both classifications. The Shannon's Diversity Index is the highest for the morphometric classes of positive forms, due to the highest number and even spatial distribution of classes. However, the negative forms has lower number of morphometric classes and the form distribution between classes is more even, therefore the diversity index is lower, though still higher than of the hierarchy levels of positive forms. Shannon's Evenness Index is the lowest for hierarchy levels, as simple dunes occur more often (almost $60 \%$ ) than complex dunes.

The morphometric classes of negative and positive forms have similar values indicating even distribution between the classes, while considering class areas prominent dominance is not characteristic. Dominance values support these results. Negative form morphometric classes have the lowest dominance value referring to the most even spatial distribution, however positive morphometric class values are only slightly higher. But hierarchy levels of positive forms show strong dominance, simple dunes are more abundant.

Nearest neighbour distance describes the isolation of a form. The average value for negative forms is almost four times higher than for positives, indicating that blowouts are scattered throughout the region, they are situated far from each other and stand alone. In contrast, positive forms tend to cluster: they are close to each other, often connected or superimposed on each other. Values for hierarchy levels is slightly higher than the average as complex dunes are concentrated in the accumulation zones, therefore the nearest neighbour of the same hierarchy level might 
be located in another group or in another accumulation zone. However, due to the dominance of simple dunes, hierarchy levels has lower nearest neighbour distances than of morphological classes, as simple dunes appear close to each other in rows. No morphometric class is dominant for neither positive nor negative forms, therefore members are located in larger distance, but evenly distributed throughout the region.

\section{Comparison of positive and negative landforms}

Based on the distribution of hierarchy levels, three accumulation zones could be identified where all superimposed hierarchy levels (Level 1-4) appear (GYörgYövics, K. and KIss, T. 2013). Thus northern, central and southern accumulation zones were identified, while the rest of the region is considered as an erosion-transportítion zone (also mentioned as matrix). The matrix encloses the three accumulation zones and only hierarchy level 1-3 dunes appear in it. Accumulation zones are in elevated position, and 54-67 percent of their area is covered by dunes, while this is only 16 percent for the erosion-transportation zone.

Characteristic of the erosion-transportation zone (matrix)

The area of the erosion-transport zone is nine times larger than the area of the accumulation zones, and the area of dunes located here is more than two times greater. This indicates numerous, but small size forms were built of the deflated sand (Table 3). Form density is considerably lower in the matrix than in the accumulation zones, referring to the erosion aspect of the erosion-transport zone. The coverage of positive forms is low (16\%), while 83 percent of negative forms are situated here (with form density of 1.7 form $/ \mathrm{km}^{2}$ ).

The reason for higher specific form number in the matrix, than in the accumulation zones, is the abundance of small dunes which were quickly stabilised and became detached from large migrating forms. The mean form area is also the lowest in the erosion-transport zone $\left(0.07 \mathrm{~km}^{2}\right)$, however, it is only slightly higher in the accumulation zones (0.08-0.15 $\mathrm{km}^{2}$ ). The standard deviation of form area is very high $\left(0.09 \mathrm{~km}^{2}\right)$ considering the mean form area, but it is still low compared to $0.31-0.65 \mathrm{~km}^{2}$ in the accumulation zones. This shows that small dunes are characteristic in the erosion-transportation zone, however, these forms are dissected and unfilled as their mean form edge is high $(1.43 \mathrm{~km})$. The shape index describes clearly the difference of zone characteristics, which is higher in the erosion-transportation zone, than in the accumulation zones. Only half of the transported material was deposited in the erosion-transportation zone which covers 90 percent of the region, so scattered forms stabilised during transport dominate the area creating a less vivid landscape.

The erosion-transportation zone contains only 4 dune hierarchy levels, as the most elevated hierarchy level 4 does not appear. This is presumably the result of less entangled dunes and lower degree of superimposition. Sand was transported further South, thus conditions for development of elevated hierarchy levels were not favourable. Due to the lower number of hierarchy levels diversity indices are the lowest in the erosion-transport zone. Here the low Shannon's Evenness Index for hierarchy levels along with the high dominance point to the prevalence of simple dunes. Lower ratio of entangled dunes also indicates the importance of transport processes in the matrix. Morphometric classes have higher diversity indices in all zones than hierarchy levels due to the greater number of forms. Dominance is less characteristic between morphometric classes: however widespread abundance of wing fragments and medium-size parabolic dunes also confirms intense erosion and transportation processes in the matrix. Positive forms are scattered in the erosion-transportation zone, as their average nearest neighbour distance is $52 \mathrm{~m}$. 
Table 3. Landscape indices for the accumulation zones and the matrix

\begin{tabular}{|c|c|c|c|c|c|c|c|c|}
\hline \multirow{2}{*}{ Landscape index } & \multicolumn{6}{|c|}{ Accumulation zone } & \multirow{2}{*}{\multicolumn{2}{|c|}{ Matrix }} \\
\hline & \multicolumn{2}{|c|}{ Northern } & \multicolumn{2}{|c|}{ Central } & \multicolumn{2}{|c|}{ Southern } & & \\
\hline Total zone area, $\mathrm{km}^{2}$ & \multicolumn{2}{|c|}{48.72} & \multicolumn{2}{|c|}{11.88} & \multicolumn{2}{|c|}{103.48} & \multicolumn{2}{|c|}{$1,446.05$} \\
\hline Total form area, $\mathrm{km}^{2}$ & \multicolumn{2}{|c|}{32.81} & \multicolumn{2}{|c|}{6.57} & \multicolumn{2}{|c|}{56.65} & \multicolumn{2}{|c|}{237.90} \\
\hline Coverage, $\%$ & \multicolumn{2}{|c|}{67.33} & \multicolumn{2}{|c|}{55.31} & \multicolumn{2}{|c|}{54.74} & \multicolumn{2}{|c|}{16.45} \\
\hline Number of patches & \multicolumn{2}{|c|}{386} & \multicolumn{2}{|c|}{64} & \multicolumn{2}{|c|}{378} & \multicolumn{2}{|c|}{3,576} \\
\hline Specific form number, form $/ \mathrm{km}^{2}$ & \multicolumn{2}{|c|}{11.77} & \multicolumn{2}{|c|}{9.74} & \multicolumn{2}{|c|}{6.67} & \multicolumn{2}{|c|}{15.03} \\
\hline Form density, form $/ \mathrm{km}^{2}$ & \multicolumn{2}{|c|}{7.92} & \multicolumn{2}{|c|}{5.39} & \multicolumn{2}{|c|}{3.65} & \multicolumn{2}{|c|}{2.47} \\
\hline Mean form area, $\mathrm{km}^{2}$ & \multicolumn{2}{|c|}{0.08} & \multicolumn{2}{|c|}{0.10} & \multicolumn{2}{|c|}{0.15} & & 0.07 \\
\hline Form area standard deviation, $\mathrm{km}^{2}$ & & .54 & & .31 & & .65 & & 0.09 \\
\hline Total edge, $\mathrm{km}$ & & 96 & & 32 & & .67 & 5,114 & 4.35 \\
\hline Mean form edge, $\mathrm{km}$ & & .19 & & .44 & & .76 & & 1.43 \\
\hline Edge density, $\mathrm{km} / \mathrm{km}^{2}$ & & .42 & & .77 & & .42 & & 3.54 \\
\hline Shape index & & .62 & & .58 & & .62 & & 1.68 \\
\hline Perimeter/area ratio & & .05 & & .03 & & .03 & & 0.03 \\
\hline Total volume, $\mathrm{km}^{3}$ & & .18 & & 014 & & .22 & & .44 \\
\hline & $\begin{array}{c}\text { Morph. } \\
\text { class }\end{array}$ & $\begin{array}{l}\text { Hier. } \\
\text { level }\end{array}$ & $\begin{array}{c}\text { Morph. } \\
\text { class }\end{array}$ & $\begin{array}{l}\text { Hier. } \\
\text { level }\end{array}$ & $\begin{array}{c}\text { Morph. } \\
\text { class }\end{array}$ & $\begin{array}{l}\text { Hier. } \\
\text { level }\end{array}$ & $\begin{array}{c}\text { Morph. } \\
\text { class }\end{array}$ & $\begin{array}{l}\text { Hier. } \\
\text { level }\end{array}$ \\
\hline Number of classes and levels & 7 & 5 & 7 & 4 & 7 & 5 & 7 & 4 \\
\hline Shannon's Diversity Index & 1.41 & 0.97 & 1.60 & 0.87 & 1.34 & 1.05 & 1.65 & 0.64 \\
\hline Shannon's Evenness Index & 0.73 & 0.60 & 0.82 & 0.62 & 0.69 & 0.65 & 0.85 & 0.46 \\
\hline Dominance & 0.53 & 0.64 & 0.35 & 0.52 & 0.61 & 0.56 & 0.29 & 0.75 \\
\hline Nearest neighbour distance, $\mathrm{m}$ & 7 & & & & 15 & & 52. & \\
\hline Class nearest neighbour distance, $\mathrm{m}$ & 194 & 61 & 300 & 136 & 327 & 135 & 355 & 117 \\
\hline
\end{tabular}

\section{Comparison of the accumulation zones}

Accumulation zones cover only 10 percent of the region, however, they contain almost half $(48 \%)$ of the transported material. Among the three accumulation zones, the central zone is the smallest, therefore it has the lowest number of forms, yet coverage and form density values are relatively high. The southern accumulation zone is the largest, yet the northern zone contains the most forms, therefore, coverage and form density are the highest here. Mean form area increases downwind (from North to South), which means that sand deposited in larger dunes in the south. But as standard deviation of form area is also the highest here, forms with different sizes appear indicating that the most entangled dunes developed in this zone, so southward migration terminated - presumably due to the nearby Drava River - and forms were stabilised.
However, due to the larger number of forms, the total form edge is higher in the southern, than in the northern accumulation zones. Mean form edge increases windward (Figure 2, A) indicating the formation of increasingly complex dunes during migration and as a result of several sand movement phases (KIss, T. et al. 2012). Edge density decreases downwind (Figure 2, B) referring to increased infilling of the dunes southward. The mean perimeter/area ratio shows similar trend (Figure 2, D), however, differences are not prominent. Despite the lower number of forms, total volume is the highest in the southern accumulation zone (Figure 2, C) which confirms that most of the sediment was deposited here.

In the central accumulation zone, hierarchy level 4 dunes do not appear. This is probably the result of the small area of the zone and the location of surrounding brooks (Szabási Rinya and Lábodi Rinya) which limited the 


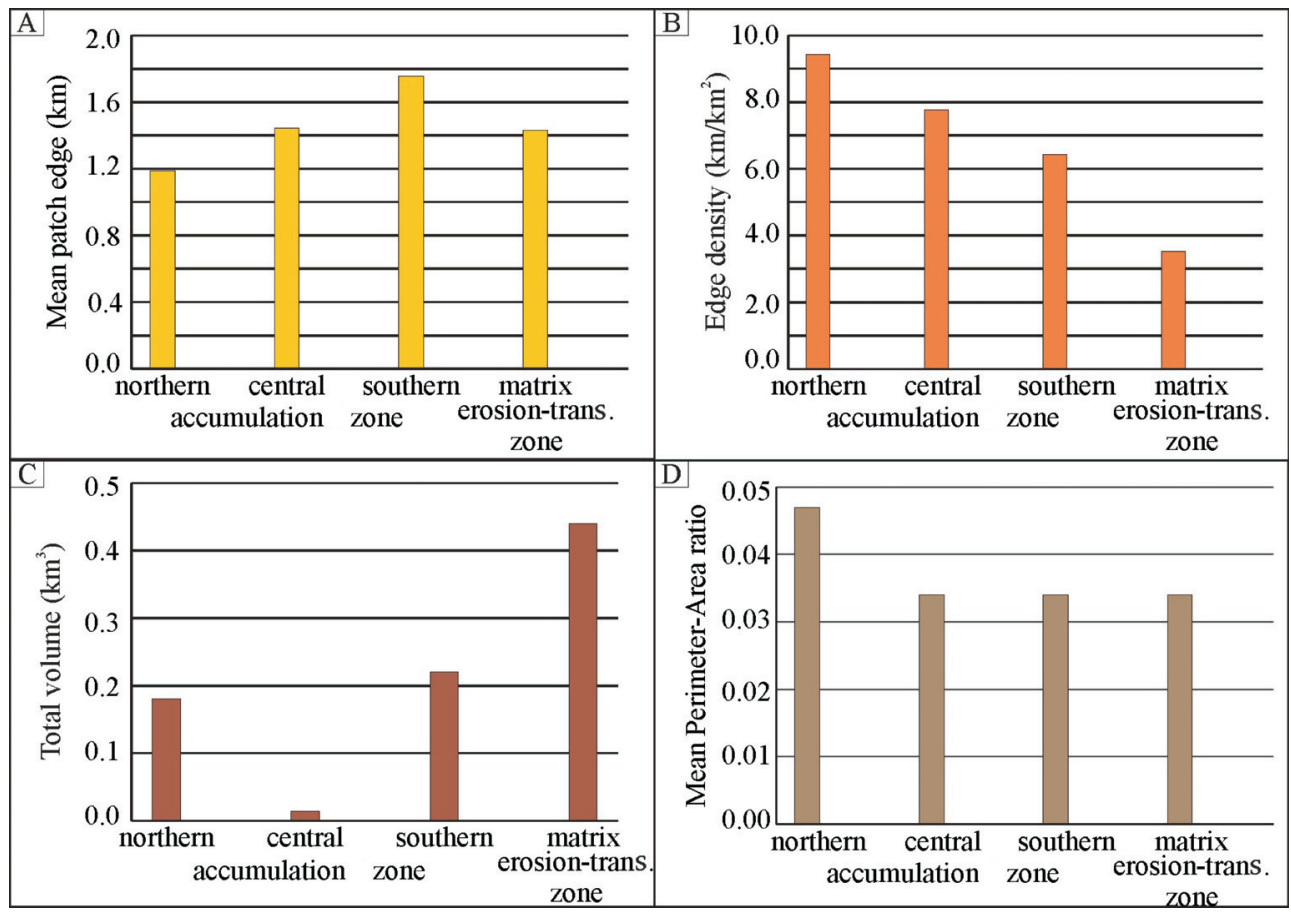

Fig. 2. Landscape indices of positive forms shows increase in the infilling (sand supply) of dunes and decrease in the complexity of their base line downwind

area of the zone. Besides, this part of the region is situated higher above sea level, therefore stronger winds are characteristic which restricted the formation of high dunes. In agreement with the lower number of hierarchy levels, diversity indices are the lowest in the central accumulation zone.

Considering the morphometric classes, the Shannon's Diversity Index is the highest in the central accumulation zone as here due to the lower number of forms form distribution is more even, while lowest diversity index in the southern accumulation zone refers to less even form distribution between classes. The reason of this is that the medium-size filled and partially filled parabolic dunes and wing fragments are abundant here, indicating that dune migration was an important process here. However, similarly high abundance of large parabolic dunes proves that significant amount of sand is stabilised in the southern accumulation zone. Shannon's
Evenness Index and dominance also confirms these findings. Considering hierarchy levels, the Shannon's Diversity Index is the highest, while Evenness Index and dominance are the lowest in the southern accumulation zone, because here all hierarchy levels appear with numerous members in all levels. The northern accumulation zone has a lower value, as hierarchy level 4 dune-class contains only one single dune and hierarchy level 3 class has only a couple of forms, while in the central accumulation zone the most elevated level (4) did not evolve at all.

Nearest neighbour distance is considerably lower in the accumulation zones than in the erosion-transport zone, as forms are entangled here and superimposed on each other resulting in the development of hierarchy levels. According to nearest neighbour distances calculated for all forms and for members of morphometric classes, dunes in the northern zone tend to cluster the most, while 
forms in the central and southern zones were stabilised in a more scattered distribution. So in the windward part of the region many forms developed close to each other, while downwind entanglement decreases, during migration forms moved apart and stabilised in a scattered locations.

\section{Spatial distribution of landforms within the region}

The distribution map of the volume of positive and negative landforms reveals the locations of deflation and deposition. When hexagonal units of positive forms have low values (Figure 3, A), it indicates dunes stabilised during transportation. Entanglement is characteristic only in the accumulation zones, where sand is concentred in the central part. High volume occurs at the head of the northern and central accumulation zones. In the southern accumulation zone two deposition centres developed, on the eastern and on the western side of the head, while the centre is lower. This distribution corresponds (1) to the dune morphology described by LemMan, D.S. et al. (1998) where an axial low separates two summit points; and (2) and, two neighbouring large parabolic dunes could join during migration, forming a huge accumulation area, but their original morphology including the two heads are still recognisable.

Volume of the negative forms is less concentrated (Figure 3, B), so as described earlier, apart from the middle areas, sand was

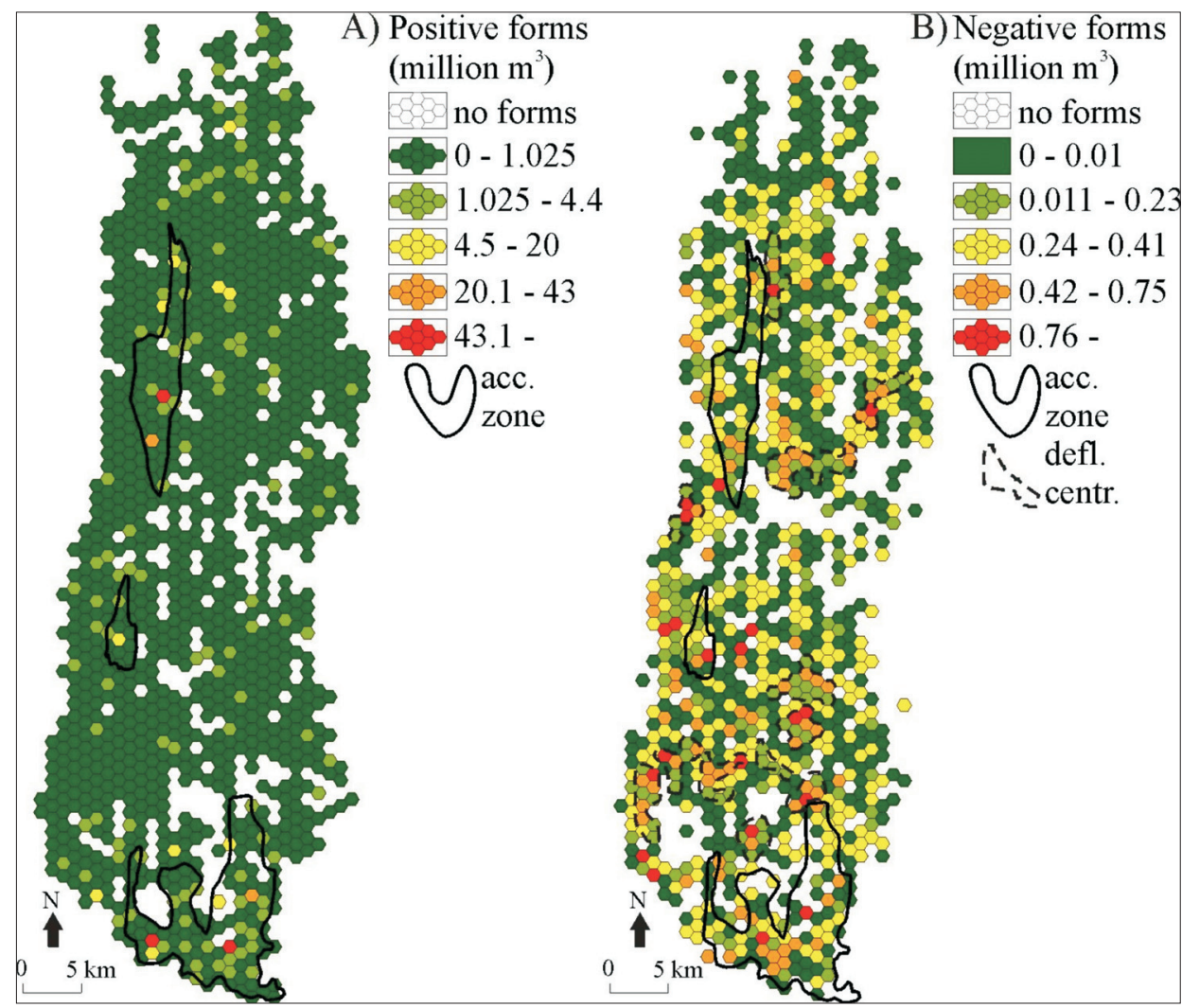

Fig. 3. Volume of the material deposited in positive forms (A), and volume of sand blown away from negative forms (B). 
blown out from small patches all across the region. The northernmost part has more consolidated sand, thus deflation create many small depressions, but altogether the volume of transported sand was low, and only slowly increased southward. The number of negative forms is low in the centres of the accumulation zones; however, during the formation of the hierarchy levels many blowouts developed in the depositional areas thus a considerable volume of sand was deflated. Yet, the major part of the sand transported from blowouts was deflated from the erosion-transportation zone, where belts with varied amount of deflation are defined (deflation centres).

\section{Conclusions}

The research has proved, that the distribution of aeolian landforms could be described applying landscape metrics, and landscape metric indices are useful to outline the accumulation or erosion zones precisely. Thus, this method could be generally used in evaluating geomorphological features, however some modifications and different interpretations had to be concerned. Some conventional landscape metric indices could not be applied. For example dunes are rarely and negative forms are never connected, therefore contagion and joint boundary type indices could not be applied in this study. Instead, nearest neighbour distance was calculated to describe the entanglement or scattering of the forms, which turned out to be a very useful parameter.

Based on the applied indices it seems, that in Inner Somogy the sand eroded from many small blowouts built up one larger dune. However, the standard deviation of form area indicates that the blown material stabilised in small positive forms at regions of higher moisture content and during low intensity sand movement periods. The shape index shows that rounded negative features are more frequent, while positive forms have more complex shape. The nearest neighbour distance index resulted in a new insight into the development history of the area, as it indicates, that blowouts evolved in a certain distance from each other, therefore they stand alone, while entanglement is very common among positive forms which are often linked or superimposed. To calculate diversity indices, hierarchy levels and morphometric classes were considered as ecological classes. This way it was determined that simple dunes dominate the hierarchy levels, while both positive and negative forms are more evenly distributed between morphometric classes.

The coverage of positive forms is $20.7 \%$ in Inner Somogy, while this value is 24.4 percent in the Southern Nyírség (KIss, T. 2000). This is probably because Inner Somogy received more annual precipitation, thus high moisture content of the sand limited dune formation. In the unconsolidated sand of the dry deserts coverage values are even higher, 27-90 percent (LANCAster, N. 1995). In the contrary, positive form density is higher in Inner Somogy (2.74 form $\left./ \mathrm{km}^{2}\right)$, than in Nyírség (2.4 form $/ \mathrm{km}^{2}$ - Kiss, T. 2000). This refers to smaller forms, which presumably also developed due to more consolidated sand, as higher moisture content enabled the quick stabilisation of dunes, thus wing fragments became isolated during migration.

Acknowledgements: This research was realized by the HURO/1101/126/2.2.1 EnviArch project and the OTKA 83561.

\section{REFERENCES}

Ádám ,L., Marosi, S. and SzILÁrd, J. 1981. Dunántúlidombság: Dél-Dunántúl (Transdanubian Hills: South Transdanubia), Budapest, Akadémiai Kiadó.

Buyantuyev, A., Wu, J. and Gries, C. 2010. Multiscale analysis of urbanization pattern of the Phoenix metropolitan landscape of USA: Time, space and thematic resolution. Landscape and Urban Planning 94. 206-217.

Сноцnоку, J. (no date) Somogy vármegye természeti viszonyai (Natural environment of Somogy County). Magyarország vármegyéi és városai, Somogy vármegye, Budapest.

Csorba, P. 2008. Potential applications of landscape ecological patch-gradient maps in nature conserva- 
tional landscpe planning. Acta Geographica Debrecina Landscape and Environment 2. 160-169.

Cushman, S.A., McGarigal, K. and Neel, M.C. 2008. Parsimony in landscape metrics: Strength, universality and consistency. Ecological Indicators 8. 691-703.

DivÉNYI, P. 2001. Topográfiai térképek - a háromdimenziós valóság (Topographic maps - the 3D reality). Summary of the paper. MFTTT Annual Meeting, Szombathely.

FAN, C. and Myint, S. 2014. A comparison of spatial autocorrelation indices and landscape metrics in measuring urban landscape fragmentation. Landscape Urban Planning 121. 117-128.

Frank, S., Fürst, C., Koschke, L., Witt, A. and MaKeschin, F. 2013. Assessment of landscape aesthetics - validation of a landscape metrics-based assessment by visual estimation of the scenic beauty. Ecological Indicators 32. 222-231.

Góczán, L. 1961. Vita Magyarország természeti földrajzi tájbeosztásáról (Debate about the physical geography regions of Hungary). Földrajzi Értesitó 10. 258-264.

GYörgyövics, K. and KIss, T. 2013. Dune hierarchy and morphometric classes of the parabolic sand dune association of Inner Somogy, Hungary. Studia Geomorphologica Carpatho-Balcanica 47. (1): 31-48.

Hai, P.M. and Yamaguchi, Y. 2007. Characterizing the urban growth from 1975 to 2003 of Hanoi city using remote sensing and a spatial metric. Forum Geografic 21. 104-110.

Kiss, T. 2000. Futóhomokterületek felszíndinamikája természeti és társadalmi hatások tükrében - dél-nyírségi vizsgálatok alapján (Surface dynamics of blown sand territories considering natural processes and social effects - case study in Southern Nyírség)., PhD dissertation, Debrecen, University of Debrecen.

Kiss, T., Györgyövics, K. and Sipos, Gy. 2012. Homokformák morfológiai tulajdonságainak és korának vizsgálata Belső-Somogy területén (Morphometry and age of sand dunes in Inner Somogy, Hungary). Földrajzi Közlemények 136. (4): 361-375.

Lancaster, N. 1995. Geomorphology of desert dunes. London-New York, Routledge.

LANG, S. and TIEDE, D. 2003. " LATE Extension für ArcGIS - vektorbasiertes Tool zur quantitativen Landschaftsstrukturanalyse. Presented at German ESRI Anwenderkonferenz, Innsbruck.

Lemman, D.S., Vance, R.E., Campbell, I.A., David, P.P., Pennock, D.J., Sauchyn, D.J. and Wolfe, S.A. 1998. Geomorphic systems of the Palliser Triangle, Southern Canadian Prairies: description and response to changing climate. Geological Survey of Canada Bulletin 521.

LóKI, J. 1981. Belső-Somogy futóhomok területeinek kialakulása és formái (Development and sand forms of the blown sand area in Inner Somogy). Közlemények a Debreceni Kossuth Lajos Tudományegyetem Földrajzi Intézetéből 139. 81-107.

Malavasia, M., Santoroa, R., Cutinia, M., AcostaA, A.T.R. and CARranZA, M.L. 2013. What has happened to coastal dunes in the last half century? A multitemporal coastal landscape analysis in Central Italy. Landscape and Urban Planning 119. 54-63.

Marosi, S. 1967. Kovárványrétegek és periglaciális jelenségek összefüggésének kérdései a belsősomogyi futóhomokban (Relationships between „kovárvány” bands and periglacial phenomena in the blown sand of Inner Somogy). Földrajzi Értesitó 15. (1): 27-40.

Marosi, S. 1970. Belső-Somogy kialakulása és felszinalaktana (Development and geomorphology of the Inner Somogy region). Budapest, Akadémiai Kiadó.

McArthur, R.H. and Wilson, E.O. 1967. The theory of island biogeography. Princeton, Princeton University Press.

McGarigal, K. and Marks, B. 1995. FRAGSTATS. Spatial pattern analysis program for quantifying landscape structure. USDA Forest Service General Technical Report PNW-GTR-351. Portland, OR, Pacific Northwest Research Station.

Mezôsı, G. and BAtA, T. 2011. New results on landscape boundaries. Acta Geographica Debrecina Landscape and Environment 5. (1): 1-10.

Morelli, F.F., Pruscini, F., Santolini, R., Perna, P., Benedetti, Y. and Sisti, D. 2013. Landscape heterogeneity metrics as indicators of bird diversity: determining the optimal spatial scales in different landscapes. Ecological Indicators 34. 372-379.

Navarro-Cerrillo, R.M., Guzmán-Álvarez, J.R., Clavero-Rumbao, I. and Ceaceros, C. 2013. A spatial pattern analysis of landscape changes between 1956-1999 of Pinus Halepensis miller plantations in Montes de Malaga State Park (Andalusia, Spain). Applied Ecology and Environmental Research 11. (2): 293-311.

Pécsi, M. and Somogyi, S. 1967. Magyarország természetföldrajzi tájai és geomorfológiai körzetei (Physical geographical and geomorphological regions of Hungary). Földrajzi Közlemények 15. (4): 285-304.

Rempel, R.S., Kaukinen, D. and CARr, A.P. 2012. Patch Analyst and Patch Grid. Ontario Ministry of Natural Resources. Ontario, Centre for Northern Forest Ecosystem Research, Thunder Bay.

Ricotta, C., Corona, P. and Marchetti, M. 2003. Beware of contagion! Landscape and Urban Planning 62. (3): 173-177.

Schindler, S., von Wehrdenc, H., Poirazidis, K., HochachKa, W.M., WrbKaA, T. and Kati, V. 2015. Performance of methods to select landscape metrics for modelling species richness. Ecological Modelling 295. 107-112.

Sebe, K., Csillag, G., Ruszkiczay-Rüdiger, Zs., Fodor, L., Thamó-Bozsó, E., Müller, P. and Braucher, 
R. 2011. Wind erosion under cold climate: A Pleistocene periglacial mega-yardang system in Central Europe (Western Pannonian Basin, Hungary). Geomorphology 134. 470-482.

Su, Z.H., Lin, C., Ma, R.H., Lou, J.H. and Liang, Q.O. 2015. Effect of land use change on lake water quality in different buffer zones. Applied Ecology and Environmental Research 13. (3): 639-653.

SüMEGHY, J. 1953. Medencéink pliocén és pleisztocén rétegtani kérdései (Pliocene and Pleistocene stratigraphic problems in Pannonian Basin). Annual Report, Budapest, MÁFI.

Szaвó, Sz. 2009. Tájmetriai mérőszámok alkalmazási lehetóségeinek vizsgálata a tájanalízisben. (Examining the possible application of landscape indices in landscape analysis), Habilitation thesis, Debrecen.

Szabó, Sz. 2011. Szomszédsági mérőszámok a tájmetriában - az indexek módszertani vizsgálata (Neighbourhood related landscape metrics - Methodological evaluation of the indices). Tájökológiai Lapok 9. (2): 285-300.

Szabó, Sz., Csorba, P. and Varga, K. 2008. Landscape management and land use - tools for landscape management. Dissertation Comissions of Cultural Landscape. Methods of Landscape Research 8. 7-20.

Szabó, Sz., Csorba, P. and Szilassi, P. 2012. Tools for landscape ecological planning - scale, and aggregation sensitivity of the contagion type landscape metric indices. Carpathian Journal of Earth and Environmental Sciences 7. (3): 127-136.

Szilassi, P., Jordán, Gy., Kovács, F., van Rompaey, A. and van Dessel, W. 2010. Investigating the link between soil quality and agricultural land use change. A case study in the lake Balaton catchment, Hungary. Carpathian Journal of Earth and Environmental Sciences 5: 61-70.
Telbisz, T. 2011. Large-scale relief of the Slovak Karst and Aggtelek Karst (Gömör-Torna / Gemer-Turňa Karst) - a DEM-based study. Hungarian Geographical Bulletin 60. (4): 379-396.

Turetta, A.P.D., Prado, R.B. and Valladares, G.S. 2013. Evaluating the potential of landscape metrics in supporting landscape planning in Atlantic forest: Rio de Janeiro, Brazil. International Journal of Agricultural and Environmental Information Systems 4. 55-67.

TÚRI, Z. 2011. A tájmintázat vizsgálata a Tiszazugban (Investigation of landscape pattern in the Tiszazug region). Tájökológiai Lapok 9. (1): 43-51.

Turner, M.G., Gardner, R.H. and O'Neill, R.V. 2001. Landscape ecology in theory and practice: pattern and process. New York, Springer.

UuemaA, E., Mander, Ü. and MarJa, R. 2013. Trends in the use of landscape spatial metrics as landscape indicators: a review. Ecological Indicators 28. 100-106.

Ye, Y., Zhang, J., Chen, L., OuYang, Y. and Parajuli, P. 2015. Dynamics of ecosystem service values in response to landscape pattern changes from 1995 to 2005 in Guangzhou, Southern China. Applied Ecology and Environmantal Research 13. (1): 21-36.

Zвoray, Z. and Kevei-BÁrány, I. 2005. A dolinák korróziós felszínének meghatározása digitális domborzatmodell alapján (Determing the corrosion surface of dolines based on digital terrain model), Karsztfejlődés X. Szombathely, 221-228. 